\title{
Antigen-specific CD4+ $T$ cells drive airway smooth muscle remodeling in experimental asthma
}

\author{
David Ramos-Barbón, ${ }^{1}$ John F. Presley, ${ }^{2}$ Qutayba A. Hamid, ${ }^{1}$ Elizabeth D. Fixman, \\ and James G. Martin'1 \\ ${ }^{1}$ Meakins-Christie Laboratories and ${ }^{2}$ Department of Anatomy and Cell Biology, McGill University, Montreal, Quebec, Canada.
}

\begin{abstract}
Airway smooth muscle (ASM) growth contributes to the mechanism of airway hyperresponsiveness in asthma. Here we demonstrate that $\mathrm{CD}^{+} \mathrm{T}$ cells, central to chronic airway inflammation, drive ASM remodeling in experimental asthma. Adoptive transfer of $\mathrm{CD}^{+} \mathrm{T}$ cells from sensitized rats induced an increase in proliferation and inhibition of apoptosis of airway myocytes in naive recipients upon repeated antigen challenge, which resulted in an increase in ASM mass. Genetically modified $\mathrm{CD4}^{+} \mathrm{T}$ cells expressing enhanced GFP (EGFP) were localized by confocal microscopy in juxtaposition to ASM cells, which suggests that $\mathrm{CD}^{+} \mathrm{T}$ cells may modulate ASM cell function through direct cell-cell interaction in vivo. Coculture of antigen-stimulated $\mathrm{CD}^{+} \mathrm{T}$ cells with cell cycle-arrested ASM cells induced myocyte proliferation, dependent on $T$ cell activation and direct $T$ cell-myocyte contact. Reciprocally, direct cell contact prevented postactivation $T$ cell apoptosis, which suggests receptor-mediated $\mathrm{T}$ cell-myocyte crosstalk. Overall, our data demonstrate that activated $\mathrm{CD}^{+} \mathrm{T}^{-}$cells drive ASM remodeling in experimental asthma and suggest that a direct cell-cell interaction participates in $\mathrm{CD}^{+} \mathrm{T}$ cell regulation of myocyte turnover and induction of remodeling.
\end{abstract}

\section{Introduction}

Asthma is a chronic inflammatory disorder of the airways that induces changes in airway structure, termed remodeling $(1,2)$. The changes include an increase in airway smooth muscle (ASM) mass, an increase in the size and number of mucous glands, and subepithelial fibrosis. The result is a thickened and hyperresponsive airway that gives rise to the clinical manifestations of asthma. Overall, the increase in ASM mass may be the main contributing factor to airway hyperresponsiveness $(3,4) . \mathrm{CD}^{+} \mathrm{T}$ cells with $\mathrm{Th} 2$ effector function play a pivotal role in the initiation and perpetuation of the inflammatory response in asthma (5-7). However, the relationship between airway inflammation and ASM remodeling is poorly understood.

A role for the T cell in ASM growth has been suggested by in vitro studies (8). However, the trafficking of antigen-specific $\mathrm{CD}^{+}$ $\mathrm{T}$ cells to the ASM and their ability to induce remodeling in vivo have not been addressed. Although it has been possible to model the increase in ASM by allergic sensitization followed by repeated antigen challenge in the rat (9), the role of the T cell cannot be isolated in actively sensitized animals. Here, we employed the technique of adoptive transfer to test the hypothesis that antigen-specific $\mathrm{CD}^{+} \mathrm{T}$ cells drive ASM remodeling upon encountering antigen in vivo. Adoptive transfer of $\mathrm{CD}^{+} \mathrm{T}$ cells from sensitized rats mediates late allergic airway responses and eosinophilic inflammation in naive recipients upon antigen challenge, in the absence of specific immunoglobulins (10). In the present study, $\mathrm{CD}^{+} \mathrm{T}$ cells from OVA-sensitized rats were stimulated in

Nonstandard abbreviations used: ASM, airway smooth muscle; BAL, bronchoalveolar lavage; EGFP, enhanced GFP; $\mathrm{P}_{\mathrm{BM}}$, basement membrane perimeter; PCNA, proliferating cell-associated nuclear antigen.

Conflict of interest: The authors have declared that no conflict of interest exists.

Citation for this article: J. Clin. Invest. 115:1580-1589 (2005).

doi:10.1172/JCI19711. vitro with OVA and subsequently transduced with recombinant retroviruses encoding enhanced GFP (EGFP). We exploited this stimulation and transduction protocol to generate a population of antigen-specific $\mathrm{CD}^{+} \mathrm{T}$ cells (11) that could also be localized in recipients. Our data demonstrate that following antigen challenge, these $\mathrm{CD}^{+} \mathrm{T}$ cells are localized in the vicinity of ASM or in actual contact with the myocytes. Moreover, adoptively transferred CD4+ $\mathrm{T}$ cells purified from OVA-sensitized donors regulate both proliferation and apoptosis of airway myocytes and induce an increase in ASM mass in an antigen-specific manner. In vitro, a crosstalk was established between cocultured $\mathrm{CD} 4^{+} \mathrm{T}$ cells and ASM cells in a cell-cell contact-dependent fashion. $\mathrm{CD} 4^{+} \mathrm{T}$ cells, activated by antigen, induced ASM cell DNA synthesis and proliferation only upon direct cell contact. Reciprocally, $\mathrm{CD}^{+} \mathrm{T}$ cell function was also affected by the cell contact, which prevented apoptosis of both activated and resting $T$ cells.

\section{Results}

Generation of antigen-specific, $E G F P^{+} / C D 4^{+} T$ cells by sequential in vitro antigen stimulation and retroviral transduction. We performed in vitro antigen stimulation followed by retroviral transduction to generate a population of OVA-specific $\mathrm{CD}^{+} \mathrm{T}$ cells stably expressing EGFP in order to localize transduced, antigen-specific $\mathrm{CD}^{+} \mathrm{T}$ cells relative to ASM following antigen reexposure in vivo. Recombinant retroviruses transduce only dividing cells. Thus, following stimulation by antigen-presenting cells in vitro, antigen-specific $\mathrm{CD} 4^{+} \mathrm{T}$ cells undergo cell proliferation and are selectively transduced (11). These cells can then be identified and FACS sorted on the basis of transgene expression. Following culture of total lymph node cells from OVA-sensitized rats with OVA, and transduction with recombinant retroviruses encoding EGFP, an average of $7.9 \%$ of the live cells were $\mathrm{EGFP}^{+}$(Figure 1A). The $\mathrm{EGFP}^{+}$cell population consisted almost exclusively of live $\mathrm{CD}^{+} \mathrm{T}$ cells: $87.8 \%$ of the transduced cells were viable, as assessed by propidium iodide exclusion (Fig- 

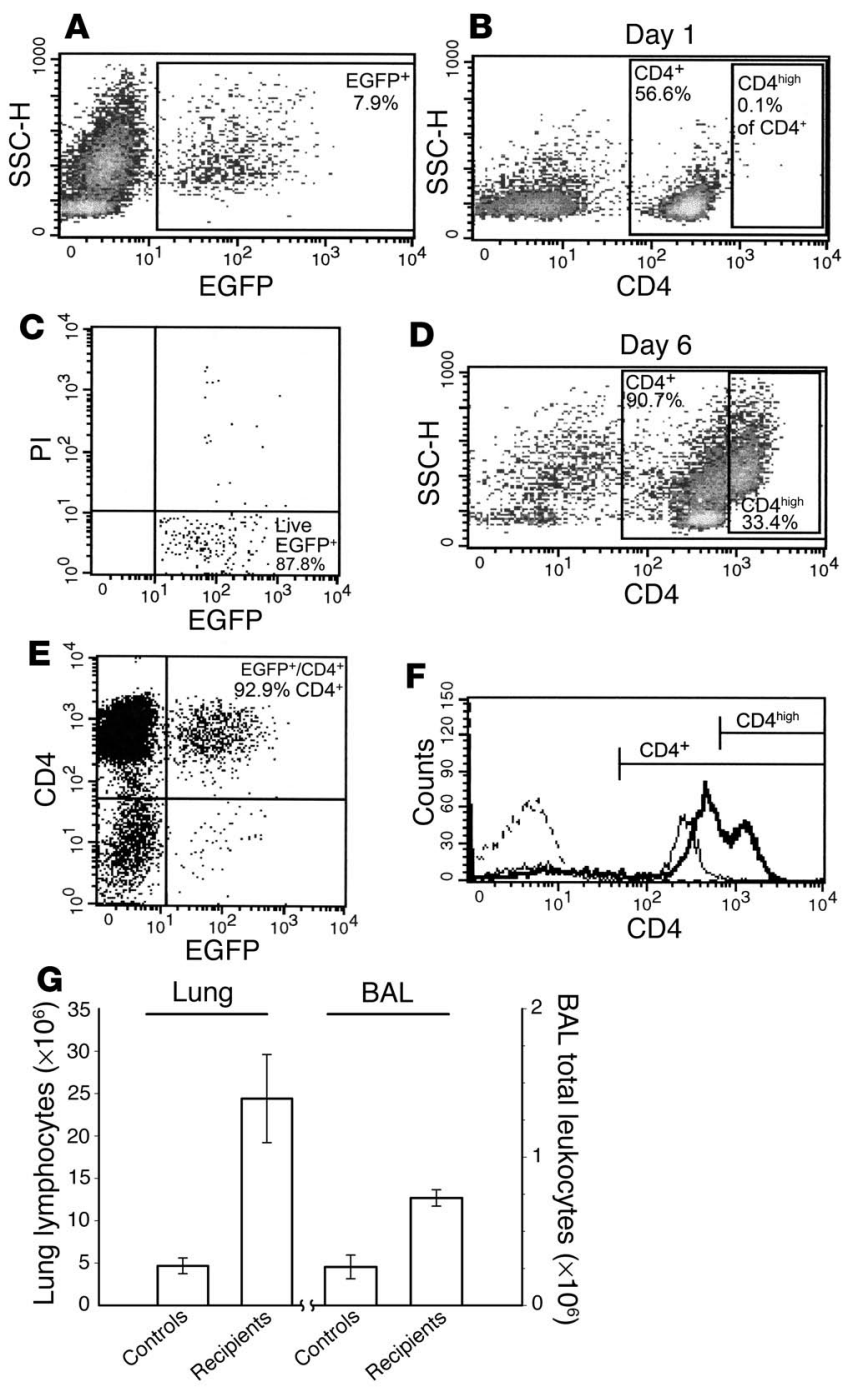

ure $1 \mathrm{C}$ ), and $92.9 \%$ of the transduced cells were $\mathrm{CD}^{+}$(Figure $1 \mathrm{E}$ ). The percentage of $\mathrm{CD}^{+} \mathrm{T}$ cells that constituted the lymph node cultures also was enriched by this stimulation protocol, increasing from $56.6 \%$ on day 1 to $90.7 \%$ by day 6 (Figure 1, B, D, and F), likely due to the combined effects of activation of antigen-specific $\mathrm{CD}^{+}$ $T$ cells and extensive death of other cell subsets. Significantly, the stimulated cells upregulated the expression of CD4 from days 3 to 6 as an effect of activation (12). This subset of $\mathrm{CD}^{+} \mathrm{T}$ cells is both selectively transduced (11) upon incubation with recombinant retroviruses and responsible for adoptive transfer of antigen-specific allergic responses (13).

Adoptive transfer of small numbers of selected antigen-specific $\mathrm{CD}^{+} \mathrm{T}$ cells induces a robust inflammatory response with infiltration of the airway wall by activated $C D 4^{+} T$ cells. On day 6 of primary cell culture we sorted the $\mathrm{EGFP}^{+}$cells by FACS and transferred $2 \times 10^{5}$ cells i.v. into unsensitized syngeneic rats. The recipient rats were challenged with aerosolized OVA or vehicle 24 hours prior to adoptive transfer, to enhance the recruitment of OVA-specific CD4 ${ }^{+} \mathrm{T}$ cells to the lungs, and rechallenged immediately following cell transfer. Forty-eight hours after transfer, total lung lymphocytes were quantified. In the recipients of $\mathrm{EGFP}^{+} / \mathrm{CD}^{+} \mathrm{T}$ cells challenged with OVA, the absolute lymphocyte numbers (range: $19.2 \times 10^{6}$ to

\section{Figure 1}

$\mathrm{CD} 4^{+} \mathrm{T}$ cell activation, retroviral transduction, and adoptive transfer of inflammatory responses. Total cell populations from sensitized lymph nodes were cultured with OVA and subsequently transduced with retroviruses encoding EGFP. (A) We identified the transduced cell population using EGFP as a selectable marker. (C) The EGFP+ cells exclude propidium iodide (PI) and are thus viable. (E) The majority of the EGFP+ ${ }^{+}$cells are CD4 ${ }^{+} \mathrm{T}$ cells, which demonstrates selective transduction of this cell type. (B, D, and F) Stimulation with OVA led to progressive enrichment of CD4+ $\mathrm{T}$ cells in the cultured population as well as upregulation of CD4 expression from day 1 to day 6 (compare $\mathbf{B}$ and $\mathbf{D}$ ). The data from $\mathbf{B}$ and $\mathbf{D}$ are presented as histograms in $\mathbf{F}$. The thin line represents the CD4 distribution in the lymph node cell population as harvested from donors on day 1 . The thick line represents the CD4 distribution following lymph node culture with OVA for 6 days. The dotted line represents the isotype control. (G) Following transduction, EGFP+ cells were sorted by FACS, and $2 \times 10^{5}$ cells were transferred into unsensitized recipients that were subsequently airway challenged with OVA. Controls were recipients of EGFP+ cells challenged with vehicle or naive animals challenged with OVA. In recipients of EGFP+ cells, the absolute number of lung lymphocytes was increased 5-fold, and the absolute number of BAL leukocytes was increased 3-fold compared with controls. Data are from 2 independent experiments. Error bars represent range.

$29.6 \times 10^{6}$ cells) averaged 5 -fold greater than those of vehicle-challenged recipients or naive controls challenged with OVA $\left(3.7 \times 10^{6}\right.$ to $5.6 \times 10^{6}$ cells) (Figure $1 \mathrm{G}$ ). In bronchoalveolar lavage (BAL), the amount of leukocyte infiltrate was 3 -fold (range: $0.67 \times 10^{6}$ to $0.78 \times 10^{6}$ cells $)$ greater than that of control animals $\left(0.18 \times 10^{6}\right.$ to $0.34 \times 10^{6}$ cells). By confocal microscopy, we localized CD $4^{+} \mathrm{T}$ cells expressing EGFP and the activation markers OX-40 and CD25 in the lungs. OX-40 (CD134) was first characterized in the rat as a specific marker of activated $\mathrm{CD}^{+} \mathrm{T}$ cells (14), and adoptive transfer experiments suggest that $\mathrm{T}$ cells expressing OX-40 may have recently encountered antigen in vivo, after transfer (15). On lung sections of the OVA-challenged recipients, we detected transduced and activated $\mathrm{CD}^{+} \mathrm{T}$ cells (Figure 2, A-E) in arteriolar walls, which suggests diapedesis; in the connective tissue bridging the vascular and airway walls; and infiltrating the airway wall, particularly the lamina propria. Significantly, $\mathrm{EGFP}^{+}$and activated T cells were also located in contact with $\alpha$-SMA-positive ASM bundles, with some labeled cells appearing to synapse with ASM cells (Figure 2 B-D). The confocal images colocalizing T cells with $\alpha$-SMA-positive ASM represent optical sections of $0.6-\mu \mathrm{m}$ thickness. Overall, this tissue distribution suggests that following antigen challenge, the transferred $\mathrm{CD}^{+} \mathrm{T}$ cells migrate from vessels into the airway wall, where they might regulate ASM function in a paracrine fashion and/or by direct cell-cell contact.

Antigen-specific $\mathrm{CD}^{+} \mathrm{T}$ cells drive an increase in ASM mass upon repeated antigen challenge. To determine whether $\mathrm{CD}^{+} \mathrm{T}$ cells were able to induce changes in the amount of ASM in an antigen-dependent fashion, we transferred purified $\mathrm{CD}^{+} \mathrm{T}$ cells from OVA- or sham-sensitized rats into unsensitized recipients, which were subsequently repeatedly airway challenged with aerosolized OVA or BSA. The transferred cell suspensions were obtained from donors by immunomagnetic negative selection and had at least $98 \% \mathrm{CD}^{+}$ $\mathrm{T}$ cell purity. Each recipient received $2 \times 10^{6} \mathrm{CD} 4^{+} \mathrm{T}$ cells i.p. Following the $\mathrm{CD}^{+} \mathrm{T}$ cell transfer, the recipients were assigned to 3 study groups. In one group (OVA/OVA group; $n=8$ ) the rats were challenged with aerosolized OVA at days 2, 5, and 8 after cell 

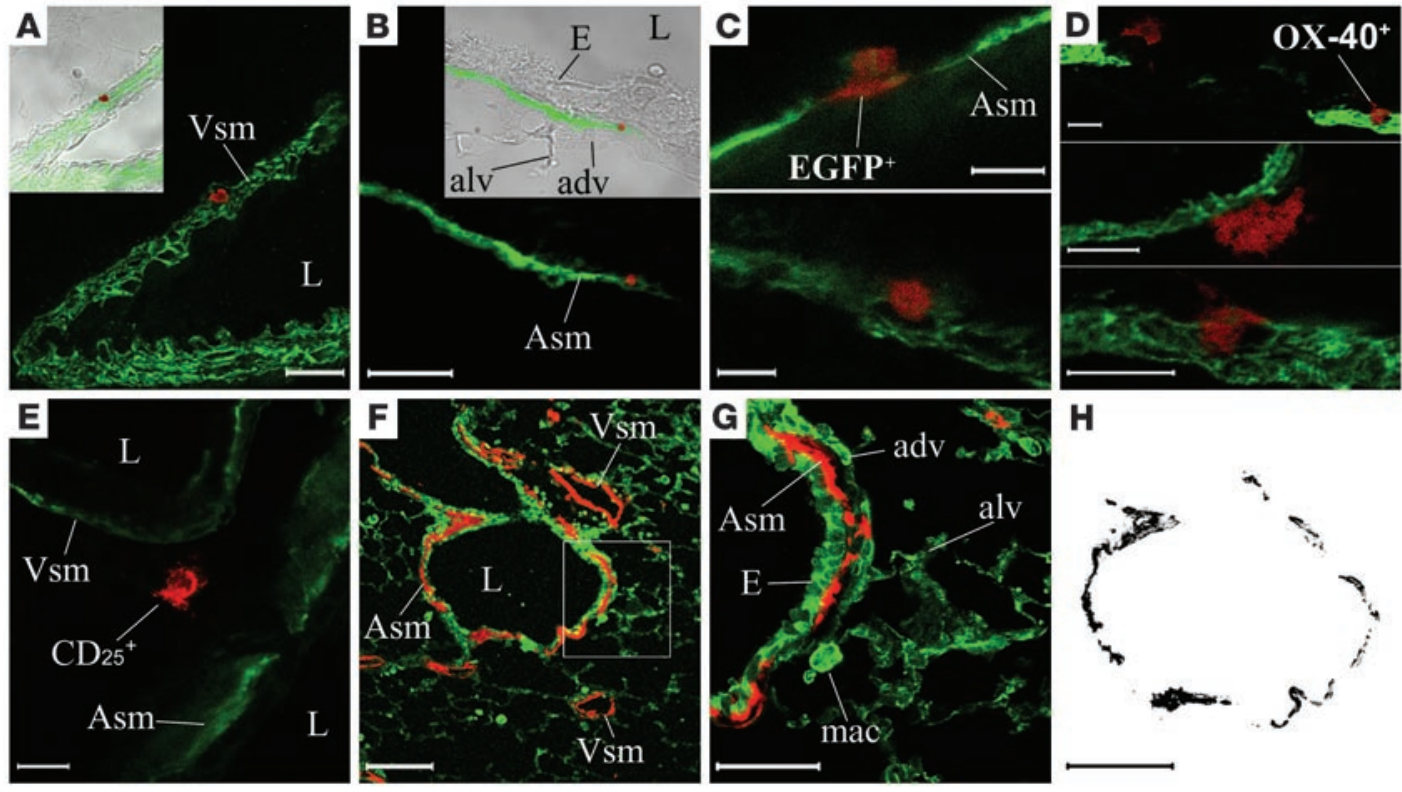

H

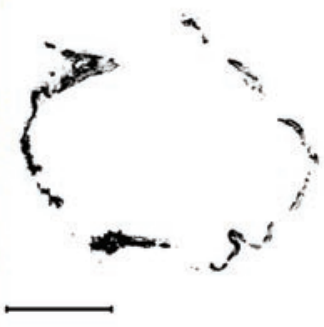

\section{Figure 2}

Confocal microscopy. (A-E) Distribution of EGFP+ $(\mathbf{A}-\mathbf{C}), \mathrm{OX}-40^{+}(\mathbf{D})$, and CD25+ $(\mathbf{E})$ cells (red signal) relative to $\alpha$-SMA (green signal). Insets in $\mathbf{A}$ and $\mathbf{B}$ show an overlay of the confocal sections over transmission histological images. (A) Example of an EGFP+ cell inside vascular smooth muscle (Vsm), likely exiting a small vessel (L, lumen). (B-D) Confocal colocalization in 0.6- $\mu$ m-thick optical sections suggesting direct contact between EGFP+ (B and C) or OX-40+ (D) cells and ASM (Asm). adv, adventitia; alv, alveolar walls; E, bronchial epithelium. (E) A CD25+ cell likely migrating between a vessel and a neighboring airway. $(\mathbf{F}-\mathbf{H})$ Confocal extraction of ASM for quantitation. $(\mathbf{F})$ In an airway, the smooth muscle bundles are identified by $\alpha$-SMA immunostaining (red). The green signal corresponds to pan-actin (all actin isoforms), which was used as a general counterstain. (G) A high-magnification field (corresponding to the square in F) illustrates the airway epithelium, smooth muscle, adventitia, alveolar walls, and alveolar macrophages (mac). (H) The ASM bundles were isolated by confocal subtraction, to measure their surface area corrected by airway size. Scale bars: $100 \mu \mathrm{m}$ (F and H); $50 \mu \mathrm{m}(\mathbf{G}) ; 20 \mu \mathrm{m}(\mathbf{A}$ and B); $10 \mu \mathrm{m}$ (D and E); and $5 \mu \mathrm{m}(\mathbf{C})$.

transfer. The rats assigned to the second group (OVA/BSA control group; $n=8$ ) were challenged with aerosolized BSA at the same time points. Rats in an additional control group (sham/OVA group; $n=8)$, which received $\mathrm{CD}^{+} \mathrm{T}$ cells from sham-sensitized donors, were OVA challenged as described above. Twenty-four hours after the final airway challenge, we harvested and fixed the lungs. On lung sections, we localized by immunofluorescence the $\alpha$-SMApositive ASM bundles and subtracted this signal from the rest of the lung tissue using confocal microscopy (Figure 2, F-H). We then calculated ASM mass by quantitative image analysis. We expressed ASM mass as a dimensionless index that is derived from ASM area normalized for airway size using the basement membrane perimeter squared $\left(\mathrm{P}_{\mathrm{BM}^{2}}\right)$. ASM mass was increased in the recipients of OVA-primed $\mathrm{CD}^{+} \mathrm{T}$ cells that were challenged with OVA (OVA/ OVA group) compared with the OVA/BSA and sham/OVA control groups (Table 1 and Figure 3). These data indicate that: (a) the increase in ASM mass observed in the OVA/OVA group was driven by antigen-specific $\mathrm{CD}^{+} \mathrm{T}$ cells, since recipients of $\mathrm{CD}^{+}$ $\mathrm{T}$ cells purified from sham-sensitized donors (sham/OVA group) did not develop this response upon challenge with OVA; and (b) the increase in ASM mass depended on the interaction between OVA-specific CD4 ${ }^{+} \mathrm{T}$ cells and OVA presented in the recipients, since $\mathrm{CD}^{+}{ }^{+} \mathrm{T}$ cells transferred from OVA-sensitized donors did not lead to increased ASM mass upon BSA challenge.

The antigen-specific, $\mathrm{CD}^{+} \mathrm{T}$ cell-dependent increase in ASM mass is associated with increased myocyte proliferation and inhibition of baseline apoptosis. To investigate the mechanisms of the antigen-specific $\mathrm{CD} 4^{+} \mathrm{T}$ cell-driven increase in ASM mass, we quantified proliferation and apoptosis of airway structural cells in lung sections of the recipient animals. We detected cell proliferation in airway sections by immunostaining for proliferating cellassociated nuclear antigen (PCNA), a DNA polymerase- $\delta$ cofactor expressed in cells progressing through the cell cycle, the expression of which peaks during the DNA synthesis phase. Apoptotic cells were identified through in situ detection of DNA fragmentation by the TUNEL technique. To demonstrate proliferation or apoptosis of ASM cells, we colocalized PCNA- or TUNEL-positive nuclei with the cytoplasmic $\alpha$-SMA staining of ASM bundles (Figure 4). We corrected the numbers of positive cells for airway size using $\mathrm{P}_{\mathrm{BM}}{ }^{2}$ as was done for ASM mass. The number of $\mathrm{PCNA}^{+}$cells per millimeter ${ }^{2}$ was significantly increased in the OVA/OVA group compared with the OVA/BSA and sham/OVA control groups, in both the airway epithelium and ASM (Table 1 and Figure 5A). This effect was present in small, medium, and large airways (Figure 5, $\mathrm{B}-\mathrm{C})$. The number of TUNEL ${ }^{+}$cells per millimeter ${ }^{2}$ in the airway epithelium and ASM was significantly decreased in the OVA/OVA group compared with the OVA/BSA and sham/OVA groups (Table 1 and Figure 5D). This effect was also significant in the partial comparisons made according to airway size in both the epithelium and ASM (Figure 5, E-F). Together, our data suggest that increased proliferation and decreased apoptosis of ASM cells contributed to the ASM remodeling induced by antigen-specific $\mathrm{CD} 4^{+} \mathrm{T}$ cells.

We used nonlinear regression analysis to fit a model of the increase in ASM mass as a dual function of increased myocyte proliferation and decreased apoptosis (Figure 6A). Details on the regression analysis are provided as supplemental material (avail- 

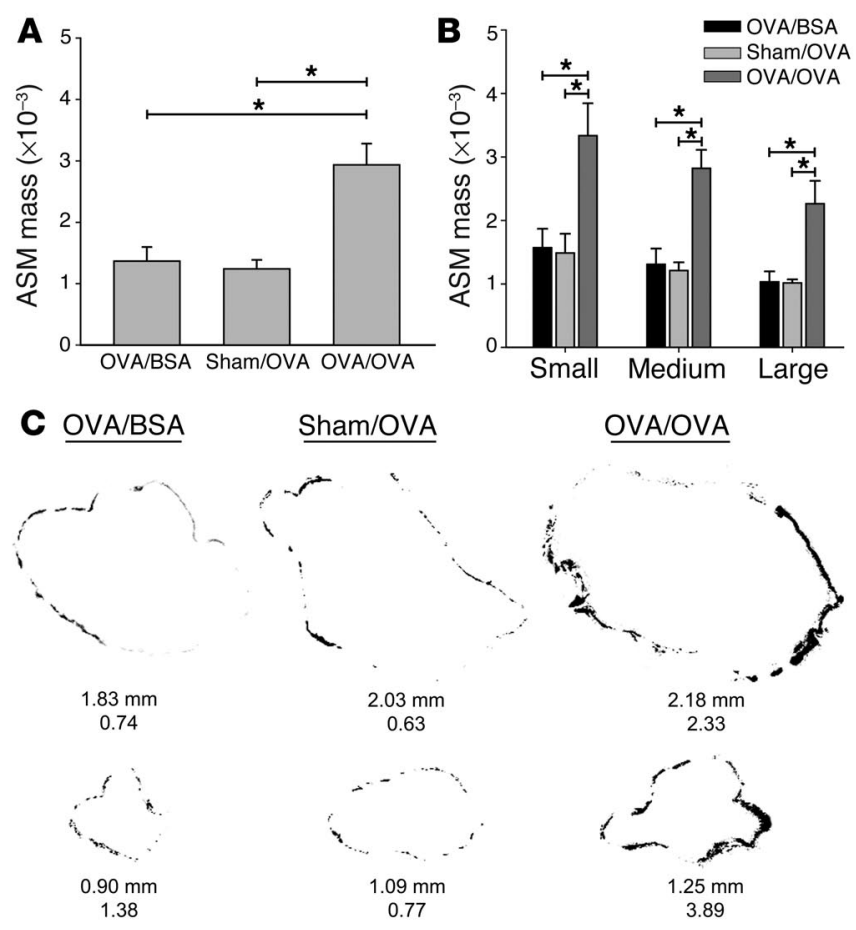

able online with this article; doi:10.1172/JCI19711DS1). The possibility that a downregulation of myocyte apoptosis significantly determined the increase in ASM mass is supported by the fact that airway size had a dual effect (Figure 6B) on the size of the decrements of myocyte apoptosis frequency (exponential, $r=-0.66$; $P=0.0012$ ) and the ASM mass increments (hyperbolic, $r=-0.45$; $P<0.0001)$ in the OVA/OVA group, whereas the airway size did not influence the increases in proliferation $(P=0.42)$. In the control groups, the relationship between ASM mass and $\mathrm{P}_{\mathrm{BM}}$ length was approximately flat (slope $=-0.11$ ), which suggests that the relative amount of ASM is a physiological constant along the bronchial tree in the rat (Figure 6B) and validates $\mathrm{P}_{\mathrm{BM}}{ }^{2}$ as an appropriate normalization for airway size.

Cell contact-dependent crosstalk between cultured ASM cells and $C D 4^{+} T$ cells activated by antigen induces ASM cell DNA synthesis and inbibits $C D 4^{+} T$ cell apoptosis. Next we tested in vitro the hypothesis, suggested by our in vivo cell tracking and confocal microscopy data, that a direct $\mathrm{T}$ cell-ASM cell contact mechanism participates in the induction of myocyte proliferation. We cocultured passage 1 cell cycle-arrested ASM cells with $\mathrm{CD}^{+} \mathrm{T}$ cells purified from OVA-sensitized donors that had been either activated with OVA in vitro or freshly harvested

\section{Figure 3}

Quantitation of ASM mass. (A) An increase of ASM mass was induced in the group receiving $C D 4^{+} T$ cells purified from OVA-sensitized donors followed by repeated airway challenge with aerosolized OVA (OVA/OVA group) compared with BSA-challenged controls (OVA/BSA group) or controls that received $C D 4^{+} T$ cells from sham-sensitized donors and were challenged with OVA (sham/OVA group). (B) The $\mathrm{CD}^{+} \mathrm{T}$ cell-driven increase in ASM mass affected small $\left(\mathrm{P}_{\mathrm{BM}}<1 \mathrm{~mm}\right)$, medium, and large $\left(P_{B M} \geq 2 \mathrm{~mm}\right)$ airways. ${ }^{*} P<0.05$. Error bars represent SE. (C) Illustrative examples of ASM, once subtracted by confocal microscopy. Airways of 2 different sizes are shown for each group. The numbers below each panel correspond to basement membrane length and ASM mass (dimensionless index, $\times 10^{-3}$ ).

and added to the ASM cell cultures without prior activation. The activated $\mathrm{CD}^{+}{ }^{+} \mathrm{T}$ cells were either allowed to establish direct cellcell contact with the myocytes or cultured in the upper chamber of a Transwell system that prevents cell contact. After 48 hours of coculture, ASM cell proliferation was analyzed by flow cytometry on the basis of BrdU incorporation during the last 24 hours of coculture, as a cumulative measurement of DNA synthesis (Figure 7). Following trypsin treatment of the cocultures, the ASM cells and the myocyte-adherent fraction of the T cells were fully dissociated. The ASM cells were resolved from the CD4 ${ }^{+} \mathrm{T}$ cells by CD 4 phenotyping combined with side-scatter profiling. Whereas baseline BrdU incorporation was $8.82 \% \pm 1.45 \%$, the addition of OVAactivated $\mathrm{CD}^{+}{ }^{+} \mathrm{T}$ cells to confluent, cell cycle-arrested ASM cells induced DNA synthesis in $26.73 \% \pm 5.32 \%$ of the myocytes only if direct cell contact was allowed $(P=0.001)$. Conversely, in Transwell cultures, where the activated T cells did not contact the ASM cells, BrdU incorporation into the ASM cells was significantly lower $(7.48 \% \pm 1.81 \% ; P=0.001)$ and did not differ from that at baseline $(P=0.778)$. In addition, only $10.02 \% \pm 3.20 \%$ of the ASM cells incor-
Table 1

ASM mass and PCNA ${ }^{+}$and TUNEL + cell frequencies

\begin{tabular}{|c|c|c|c|c|}
\hline & Group & $\begin{array}{l}\text { ASM mass or positive } \\
\text { cells } / \mathrm{mm}^{2}, \text { mean } \pm \text { SE }\end{array}$ & $P$ & Mean $\Delta ;(95 \% \mathrm{CI})$ \\
\hline \multirow[t]{3}{*}{ ASM mass $\left(\times 10^{-3}\right)$} & OVA/BSA & $1.42 \pm 0.20$ & $0.372^{A}$ & $-0.12 ;(-0.87,0.62)^{\mathrm{A}}$ \\
\hline & Sham/OVA & $1.12 \pm 0.09$ & $<0.001^{\mathrm{B}}$ & $1.69 ;(0.95,2.44)^{\mathrm{B}}$ \\
\hline & OVA/OVA & $3.25 \pm 0.41$ & $<0.001^{C}$ & $1.57 ;(0.82,2.31)^{\mathrm{C}}$ \\
\hline \multirow[t]{3}{*}{ PCNA+ cells in epithelium } & OVA/BSA & $2.76 \pm 0.60$ & $0.142^{\mathrm{A}}$ & $-1.82 ;(-4.31,0.66)^{\mathrm{A}}$ \\
\hline & Sham/OVA & $0.94 \pm 0.22$ & $<0.001^{B}$ & $4.92 ;(2.43,7.40)^{\mathrm{B}}$ \\
\hline & OVA/OVA & $5.86 \pm 1.32$ & $0.017^{C}$ & 3.092; $(0.61,5.58)^{\mathrm{C}}$ \\
\hline \multirow[t]{3}{*}{$\mathrm{PCNA}^{+}$cells in ASM } & OVA/BSA & $0.33 \pm 0.16$ & $0.912^{\mathrm{A}}$ & $-0.04 ;(-0.82,0.73)^{\mathrm{A}}$ \\
\hline & Sham/OVA & $0.28 \pm 0.14$ & $0.001^{B}$ & $1.48 ;(0.70,2.25)^{B}$ \\
\hline & OVA/OVA & $1.76 \pm 0.40$ & $0.001^{\mathrm{C}}$ & 1.43; $(0.66,2.21)^{\mathrm{C}}$ \\
\hline \multirow[t]{3}{*}{ TUNEL+ cells in epithelium } & OVA/BSA & $7.24 \pm 1.28$ & $0.133^{A}$ & $-2.23 ;(-5.20,0.74)^{\mathrm{A}}$ \\
\hline & Sham/OVA & $5.01 \pm 0.89$ & $0.041^{B}$ & $-3.11 ;(-6.09,-0.14)^{\mathrm{B}}$ \\
\hline & OVA/OVA & $1.90 \pm 0.80$ & $0.001^{c}$ & $-5.34 ;(-8.32,-2.37)^{\mathrm{C}}$ \\
\hline \multirow[t]{3}{*}{ TUNEL+ cells in ASM } & OVA/BSA & $3.49 \pm 0.63$ & $0.496^{A}$ & $-0.45 ;(-1.80,0.90)^{A}$ \\
\hline & Sham/OVA & $3.04 \pm 0.46$ & $0.003^{\mathrm{B}}$ & $-2.17 ;(-3.52,-0.81)^{\mathrm{B}}$ \\
\hline & OVA/OVA & $0.87 \pm 0.14$ & $0.001^{\mathrm{C}}$ & $-2.62 ;(-3.97,-1.27)^{\mathrm{C}}$ \\
\hline
\end{tabular}

ASM mass was calculated in cross-sectioned airways as ASM surface divided by $\mathrm{P}_{\mathrm{BM}}{ }^{2}$ to standardize by airway size, which resulted in a dimensionless index. The frequencies of $\mathrm{PCNA}^{+}$and $\mathrm{TUNEL}^{+}$cells in epithelium and $A S M$ were also referenced to $\mathrm{P}_{\mathrm{BM}^{2}}$ and are expressed as cells per millimeter ${ }^{2}$. Values are mean $\pm \mathrm{SE}$. The post-ANOVA multiple comparison $P$ values are shown. The ANOVA $P$ values are: $<0.001$ for ASM mass; 0.002 for PCNA in epithelium; 0.001 for PCNA in ASM; 0.005 for TUNEL in epithelium; and 0.001 for TUNEL in ASM. The $95 \%$ confidence intervals $(\mathrm{CI})$ of the mean increment $(\Delta)$ estimate the size of the effects. Asham/OVA versus OVA/BSA; BOVA/OVA versus sham/OVA; ${ }^{C}$ OVA/OVA versus OVA/BSA. 


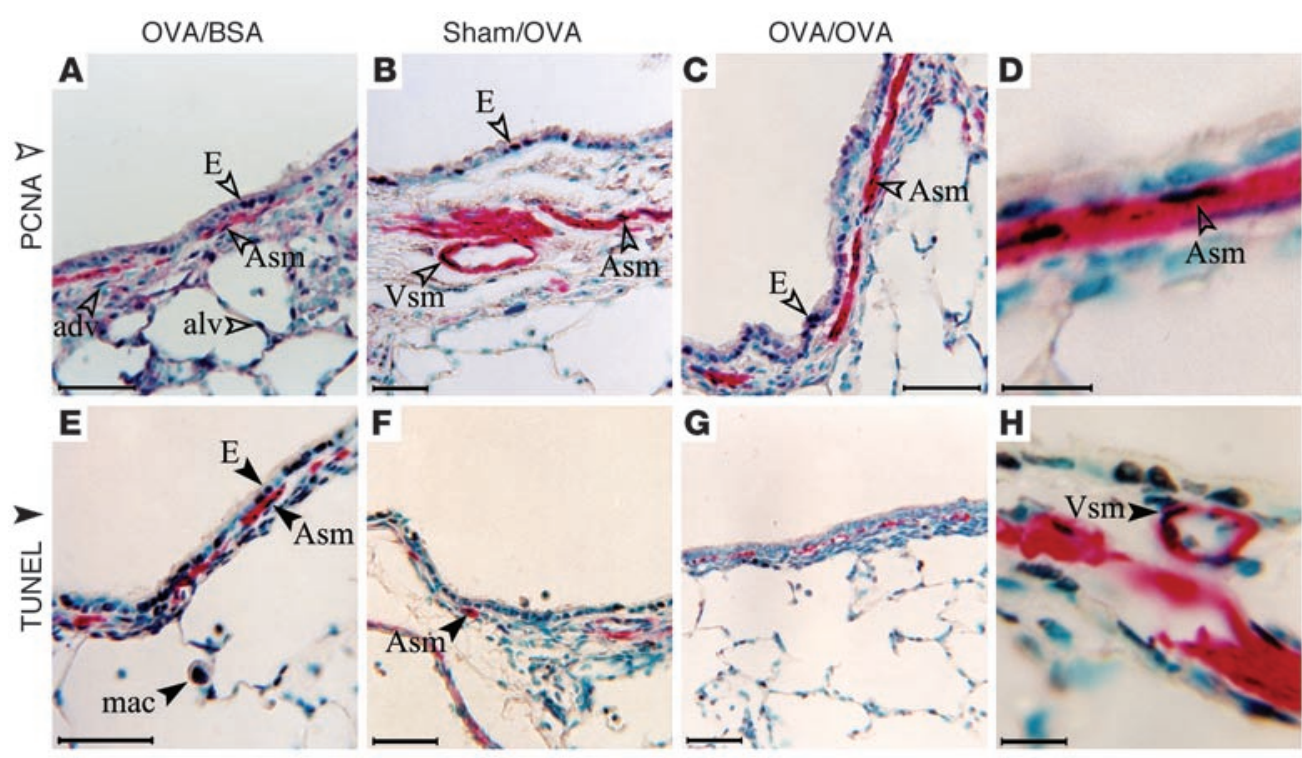

Figure 4

Colocalization of PCNA and TUNEL with $\alpha$-SMA. (A-D) Detection of proliferating cells (PCNA+, open arrowheads). (E-H) Detection of apoptotic cells (TUNEL+, filled arrowheads). Examples illustrating PCNA immunostaining and TUNEL, respectively, are shown for the OVA/BSA (A and E), sham/OVA (B and F), and OVA/OVA (C and G) groups. Both PCNA and TUNEL are shown as dark nuclear signals, colocalized with the $\alpha$-SMA ${ }^{+}$ smooth muscle bundles (red cytoplasmic signal). D and $\mathbf{H}$ illustrate at high magnification the colocalization of PCNA and TUNEL, respectively, with $\alpha$-SMA. PCNA ${ }^{+}$and apoptotic cells can also be identified in the airway epithelium, in vascular smooth muscle of bronchial arterioles, and other locations as indicated. Counterstain: methyl green. Scale bars: $50 \mu \mathrm{m}(\mathbf{A}-\mathbf{C}$ and $\mathbf{E}-\mathbf{G}) ; 10 \mu \mathrm{m}(\mathbf{D}$ and $\mathbf{H})$.

porated $\mathrm{BrdU}$ when incubated with nonactivated $\mathrm{CD}^{+} \mathrm{T}$ cell in spite of direct T cell-myocyte contact ( $P=0.007$ vs. direct contact of activated T cells; $P=0.817$ vs. baseline). The ability of activated $\mathrm{CD}^{+} \mathrm{T}$ cells to induce proliferation of ASM cells through direct contact was dose dependent $(r=0.99$; $P<0.001$; Figure 7E).

The analysis of BrdU incorporation versus DNA content in the $\mathrm{CD}^{+} \mathrm{T}$ cells cocultured with the ASM cells allowed us to distinguish several $\mathrm{T}$ cell subpopulations according to status of activation and viability, as determined by DNA synthesis and cell cycle analysis (Figure 8 and Table 2). Following activation by OVA in vitro and 48 hours of subsequent coculture with ASM cells, a fraction of the $\mathrm{CD}^{+} \mathrm{T}$ cells was progressing through the cell cycle and synthesized DNA. This $\mathrm{T}$ cell fraction comprised $\mathrm{BrdU}^{+}$cells that were in $\mathrm{S}$ or $\mathrm{G}_{2} / \mathrm{M}$ phases of the cell cycle (region 2 in Figure 8 and Table 2) plus a subpopulation of live postmitotic cells $\left(\mathrm{BrdU}^{+}\right.$cells in $G_{0} / G_{1}$ phase of the cell cycle; region 3 ) and a subpopulation of cells that underwent postactivation apoptosis $\left(\mathrm{BrdU}^{+}\right.$cells with subdiploid DNA content; region 4). Another fraction of the $\mathrm{CD}^{+}$ $\mathrm{T}$ cells, likely comprising non-OVA-specific T cells, did not incorporate BrdU and stayed quiescent (BrdU- cells in $\mathrm{G}_{0} / \mathrm{G}_{1}$ phase; region 1) or underwent apoptosis (BrdU- cells with subdiploid DNA content; region 5). In OVA-activated $\mathrm{CD}^{+} \mathrm{T}$ cells in direct contact with ASM cells, compared with $\mathrm{T}$ cells cultured in the Transwell chamber, postactivation apoptosis of the $\mathrm{BrdU}^{+} \mathrm{T}$ cells as well as spontaneous apoptosis occurring in the BrdU- resting $\mathrm{T}$ cell fraction were prevented. Significantly, the proportion of live $\mathrm{BrdU}^{+} \mathrm{T}$ cells was higher if the $\mathrm{T}$ cells were in contact with the ASM cells rather than separated from them, as those cultured in the Transwell chamber. These data suggest that OVA-activated CD4 ${ }^{+}$ $\mathrm{T}$ cells in contact with ASM cells are selectively retained in a viable, proliferating compartment as a result of the downregulation of postactivation apoptosis. Moreover, direct contact of non-OVA- activated $\mathrm{CD}^{+} \mathrm{T}$ cells with ASM cells did not elicit progression through the $\mathrm{T}$ cell cycle, which suggests that the mere adhesion of $\mathrm{CD}^{+} \mathrm{T}$ cells to ASM cells does not result in $\mathrm{T}$ cell activation. Nevertheless, the apoptosis of nonactivated $\mathrm{CD} 4^{+} \mathrm{T}$ cells was prevented by adherence to ASM cells, as shown by comparison with the BrdU- fraction of T cells cultured in Transwells (Figure 8A, top left panel, region 5).

Overall, these data suggest that $\mathrm{CD}^{+} \mathrm{T}$ cells activated by antigen establish direct crosstalk with ASM cells, eliciting reciprocal effects. In a CD4 ${ }^{+} \mathrm{T}$ cell-ASM cell contact-dependent fashion, $\mathrm{CD}^{+} \mathrm{T}$ cells previously activated by antigen induce myocyte DNA synthesis and proliferation. Furthermore, direct contact with the ASM cells largely prevents apoptosis of the T cells, which may result in prolonged survival and expansion of $\mathrm{CD}^{+} \mathrm{T}$ cells following activation by antigen.

\section{Discussion}

The data presented here support the idea that ASM remodeling, an important feature of asthma and airway hyperresponsiveness $(3,4,16,17)$, is driven by antigen-specific $\mathrm{CD}^{+} \mathrm{T}$ cells through a mechanism involving direct $\mathrm{T}$ cell-myocyte contact. We applied the methodology of Costa et al. (11), who demonstrated that a rare subpopulation of antigen-specific $\mathrm{CD}^{+} \mathrm{T}$ cells could be selectively transduced with recombinant retroviruses and subsequently sorted on the basis of transgene expression. We demonstrate here that relatively small numbers $\left(2 \times 10^{5}\right)$ of retrovirally transduced CD4 ${ }^{+}$ $T$ cells, when transferred back in vivo, migrate into the lungs and induce an amplified inflammatory response upon airway antigen challenge. This resulted in a spatial distribution of the adoptively transferred $\mathrm{CD}^{+} \mathrm{T}$ cells, which suggests that these cells may come into direct contact with the ASM in vivo. To quantify $\mathrm{CD}^{+} \mathrm{T}$ celldriven ASM growth, we transferred purified $\mathrm{CD} 4^{+} \mathrm{T}$ cells from sen- 
A
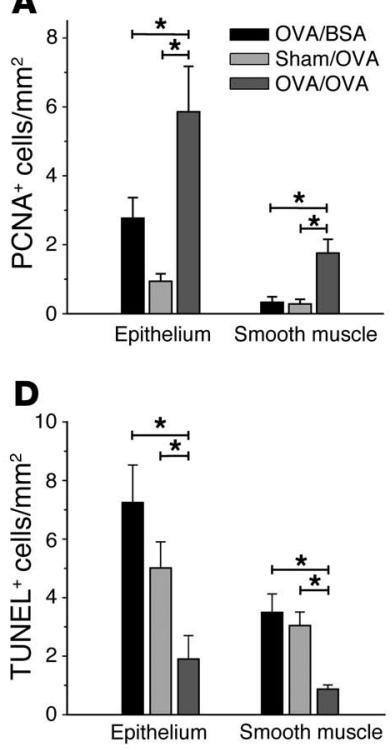

B
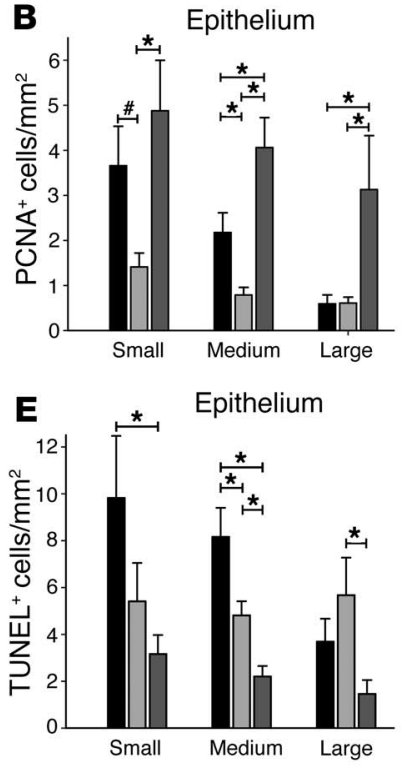

c

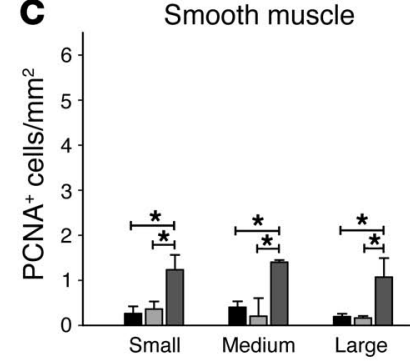

$\mathbf{F}$

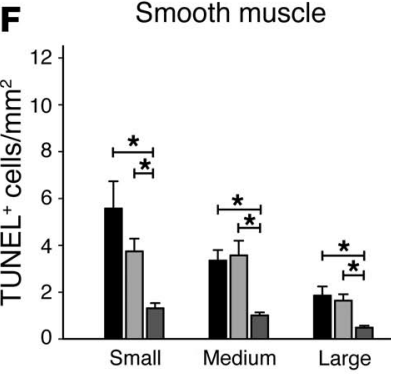

Figure 5

Quantitative morphology of cell proliferation and apoptosis in airways. (A and D) Mean PCNA+ and TUNEL+ cells per millimeter ${ }^{2}$, respectively, by experimental group. (B and E) Mean epithelial $\mathrm{PCNA}^{+}$and $\mathrm{TUNEL}^{+}$cells per millimeter ${ }^{2}$, respectively, by airway size and experimental group. ( $\mathbf{C}$ and $\mathbf{F}$ ) Mean epithelial $\mathrm{PCNA}^{+}$and TUNEL+ cells per millimeter ${ }^{2}$, respectively, in ASM cells. Error bars represent SE. ${ }^{\star} P<0.05$, post-ANOVA; " tistically borderline difference with power less than $80 \%$.

responses including calcium mobilization (22), activation of MAPK and PI3K, and expression of cyclin D1 (23). In inflammatory bowel disease, where smooth muscle hyperplasia occurs in the muscularis mucosae, peripheral blood mononuclear cells interact

sitized rats into unsensitized recipients. Previous work using this adoptive transfer model showed that the $\mathrm{CD}^{+} \mathrm{T}$ cells infiltrating the airways have a Th2 phenotype (18). Here, repeated airway challenge of the $\mathrm{CD}^{+} \mathrm{T}$ cell recipients resulted in an increase in the amount of ASM. This increase in ASM mass occurred in association with $\mathrm{CD}^{+} \mathrm{T}$ cell-dependent hyperplasia and inhibition of apoptosis of airway myocytes, which suggests that $\mathrm{CD} 4^{+} \mathrm{T}$ cells induce ASM remodeling by regulating myocyte proliferation and survival. Consistent with the confocal microscopy data suggesting direct contact between activated $\mathrm{CD}^{+} \mathrm{T}$ cells and ASM in vivo, results from experiments in vitro demonstrated $\mathrm{CD}^{+}{ }^{+} \mathrm{T}$ cell-ASM cell crosstalk, which was dependent upon direct cell contact. $\mathrm{CD} 4^{+} \mathrm{T}$ cells activated by OVA, but not resting $\mathrm{T}$ cells, induced ASM cell proliferation through a mechanism in which direct $\mathrm{T}$ cell-myocyte contact was necessary, whereas soluble $\mathrm{CD}^{+} \mathrm{T}$ cell mediators were not sufficient if the activated $\mathrm{CD}^{+} \mathrm{T}$ cells and the ASM cells were separated by a Transwell membrane. As a reciprocal effect, direct contact with the myocytes prevented postactivation $\mathrm{CD}^{+} \mathrm{T}$ cell apoptosis and also the spontaneous apoptosis of resting $\mathrm{T}$ cells and resulted in significant retention of OVA-activated, proliferating $\mathrm{CD}^{+} \mathrm{T}$ cells in the live cell compartment.

In allergen-sensitized rats, repeated airway challenge leads to an increase in ASM mass (9) of comparable magnitude to our current results, and that is caused at least in part by hyperplasia, as shown by the induction of DNA synthesis in ASM cells (19-21). However, the pathways that link airway inflammation and remodeling of the ASM remain largely unknown. Human polyclonally activated $\mathrm{T}$ cells have been shown to adhere to ASM cells through integrins and CD44 and to induce myocyte DNA synthesis in vitro (8). In cultured ASM cells, the engagement of adhesion and immune receptors such as CD40, CD44, and VCAM-1 leads to signaling events that may be involved in proliferative
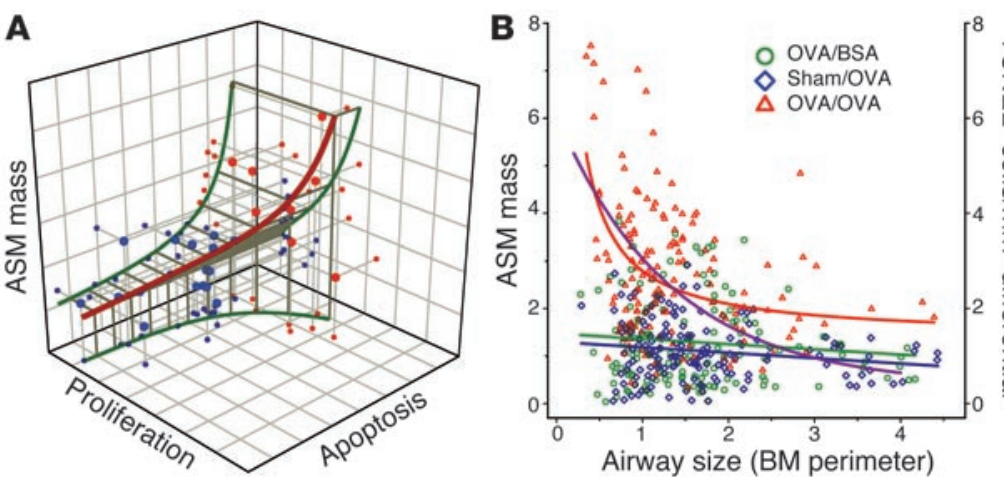

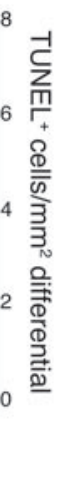

\section{Figure 6}

Regression analysis of the increase in ASM mass as a dual function of increased proliferation and decreased apoptosis of ASM cells. (A) Tri-variable projections and $3 \mathrm{D}$ reconstruction (a detailed split is shown in Supplemental Figure S1). The control groups were pooled and are represented as blue spheres for clarity. (B) Scatter plot of ASM mass $\left(\times 10^{-3}\right)$ versus airway size. The relative amount of ASM is approximately constant along the tracheobronchial tree (green and blue, OVA/BSA and sham/OVA groups, respectively). The CD4 ${ }^{+} \mathrm{T}$ cell-driven effect on ASM mass lifts and distorts this relationship (red, OVA/OVA group). The increase in ASM mass is greater the smaller the airways. The airway size also influences the effect on regulation of apoptosis; the size of the decrements in myocyte apoptosis frequency is greater the smaller the airways (TUNEL differential, right $y$ axis, violet regression curve). The influence of the airway size on apoptosis inhibition and ASM mass followed similar regression trends, whereas there was no relationship between airway size and $\mathrm{PCNA}^{+}$cell frequency (data not shown). BM, basement membrane. 
A
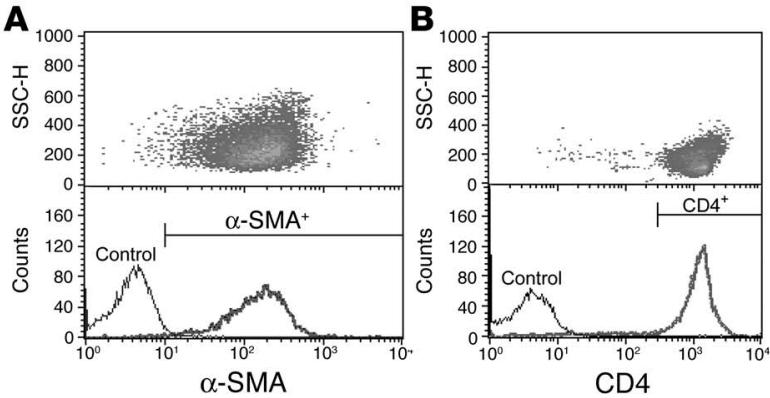

C
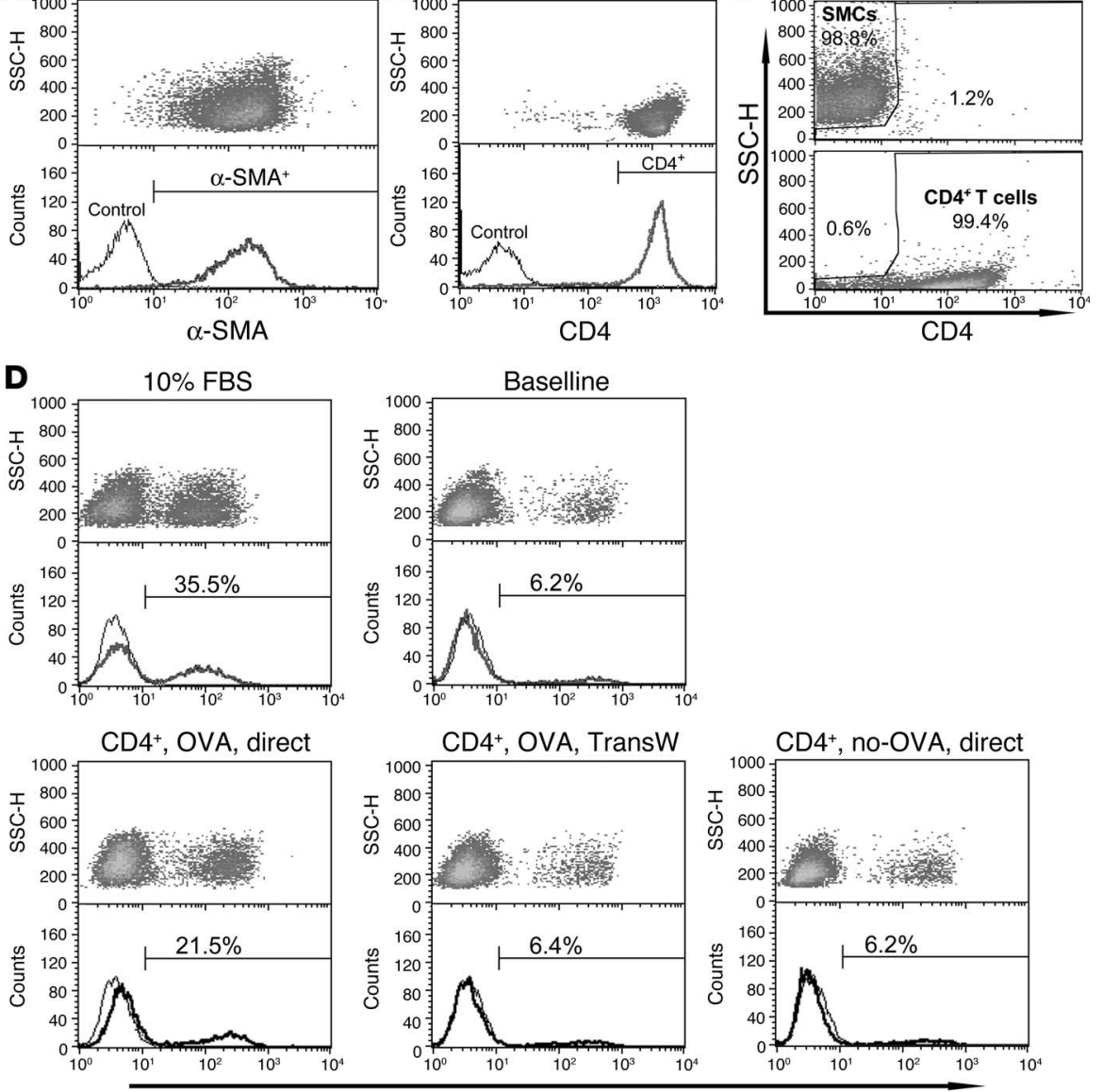

BrdU incorporation

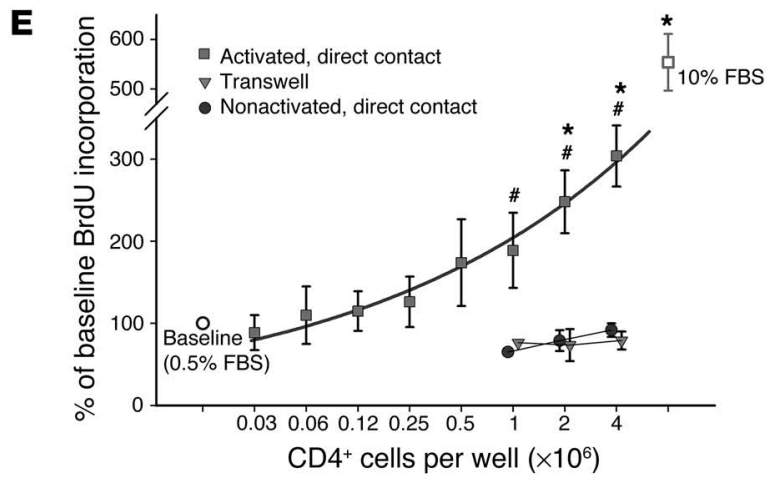

Figure 7

$\mathrm{CD}^{+} \mathrm{T}$ cells induce airway myocyte proliferation, dependent on $T$ cell activation and direct T cell-myocyte contact. (A) Ninety-nine percent of the cells in primary ASM cell cultures expressed $\alpha$-SMA. (B) CD4 ${ }^{+}$T cells (purity $\geq$ $98 \%$ ) were cocultured with the ASM cells for 48 hours, in the presence of BrdU during the last 24 hours. Cells were immunostained for $\mathrm{CD} 4$, and BrdU incorporation by the ASM cells was quantified. (C) The CD4+ $T$ cells and the smooth muscle cells (SMCs) were resolved with at least $99 \%$ specificity, as calculated from samples containing ASM cells only (upper plot) or T cells only recovered from Transwells (lower plot). In the lower plot, the left-shifted tail of the $T$ cell population reflects some loss of CD4 expression from apoptosis. (D) BrdU incorporation by ASM cells. In each panel, BrdU incorporation is represented as a density plot (upper plots) and as a histogram (lower plots, thick line) overlaid on the baseline histogram (thin lines). The percentages of $\mathrm{BrdU}^{+}$cells were calculated by subtraction. Myocytes incubated with $10 \%$ FBS served as a positive control for proliferation. The baseline BrdU incorporation was calculated from myocytes cultured in $0.5 \%$ FBS and $20 \mathrm{U} / \mathrm{ml} \mathrm{IL-2}$. The ASM cells were cocultured with: $C D 4^{+} T$ cells activated with OVA, either in direct contact (CD4 ${ }^{+}$, OVA, direct) or separated by a Transwell membrane (CD4+ ${ }^{+}$OVA, TransW); and with nonstimulated $\mathrm{CD}^{+}{ }^{+} \mathrm{T}$ cells in direct contact $\left(\mathrm{CD} 4^{+}\right.$, no-OVA, direct). Coculture in direct contact with OVAactivated $\mathrm{T}$ cells elicited a significant increase in BrdU incorporation. (E) Dose-response curve of $\mathrm{T}$ cell effect on myocyte BrdU incorporation. Data normalized as percentage of baseline. $n=3-6$ independent experiments per data point. ${ }^{*} P<0.05$ versus baseline; ${ }^{\#} P<0.05$ versus Transwell and nonactivated T cells.

T cell apoptosis that limits cellular immune responses and thus contribute to the perpetuation of airway inflammation.

Our data support the hypothesis that $\mathrm{CD}^{+} \mathrm{T}$ cell-driven inhibition of myocyte apoptosis may be another pathway involved in the remodeling of ASM. Whereas there is a general consensus that

an increase in ASM mass. Furthermore, our experiments tracking genetically modified $\mathrm{CD} 4^{+} \mathrm{T}$ cells by confocal microscopy suggest that activated antigen-specific $\mathrm{CD}^{+} \mathrm{T}$ cells may interact directly with ASM cells in vivo. This is further supported by our data demonstrating bidirectional $\mathrm{CD} 4^{+} \mathrm{T}$ cell-myocyte crosstalk through direct contact in vitro. In a reciprocal fashion, OVA-activated $\mathrm{CD}^{+}$ $\mathrm{T}$ cells induced proliferation of cell cycle-arrested ASM cells, and the ASM cells largely inhibited apoptosis of the OVA-activated T cells, which resulted in a significantly increased proportion of live, activated T cells. ASM cells may have a proinflammatory role in asthma through the secretion of cytokines (29). Our in vitro findings suggest another possibility, that $\mathrm{CD}^{+} \mathrm{T}$ cell-myocyte contact occurring in the airways may downregulate the activation-induced apoptosis participates in homeostatic cell turnover in most tissue types, little is known about the mechanisms of induction and regulation of such apoptosis and its role in tissue repair. Normal airway (30) and vascular (31) smooth muscle cells constitutively express Fas and undergo apoptosis upon Fas cross-linking, which suggests that control of myocyte number through Fas ligation may be a general mechanism for smooth muscle homeostasis. A role of Fas and FasL has also been proposed in bronchial epithelial turnover (32). Stimuli promoting repair mechanisms in asthma may act as a switch that induces proliferation and inhibits apoptosis, favoring a prolonged survival of mesenchymal and epithelial cells. In our $\mathrm{CD}^{+} \mathrm{T}$ cell-driven experiments, the growth of ASM likely occurred as a combination of both proliferation 

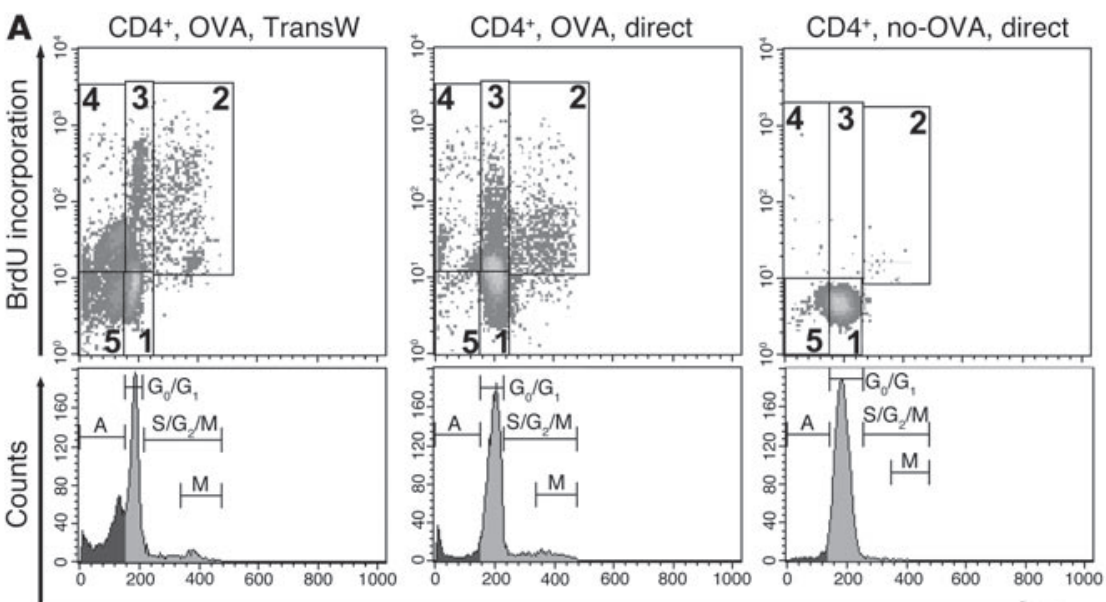

DNA
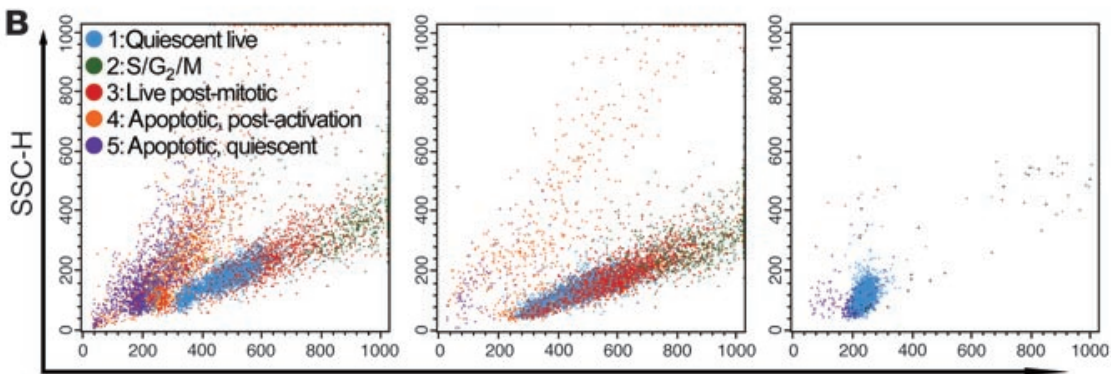

FSC-H

C

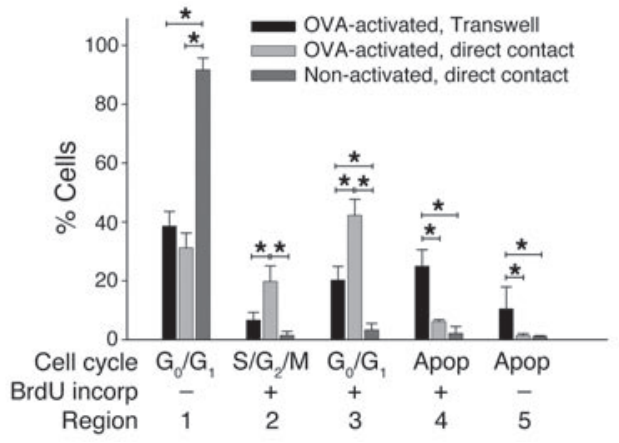

and extension of cell survival. Regression analysis of our data suggested that the observed decrease in myocyte apoptosis may have contributed to the increased ASM mass to a greater extent than hyperplasia in this model. Although this argument is based on statistical inference, the data suggest a significant role for regulation of apoptosis by $\mathrm{CD}^{+} \mathrm{T}$ cells in the ASM remodeling mechanism. Further research is necessary to identify the pathways involved in the regulation of myocyte apoptosis by $\mathrm{CD}^{+} \mathrm{T}$ cell contact. This is not readily analyzable in a straightforward coculture model, since ASM cells isolated from the airways and grown in primary culture may lack mechanisms that drive their turnover in the ASM bundles in vivo. New models mimicking such mechanisms need to be developed.

In summary, adoptively transferred $\mathrm{CD}^{+} \mathrm{T}$ cells, labeled and selected for antigen specificity using retroviral transduction, induced an amplified inflammatory response in the airways following antigen challenge. Activated $\mathrm{CD}^{+} \mathrm{T}$ cells infiltrated the airway wall, where they may have acted on ASM through pathways involving direct $\mathrm{CD}^{+} \mathrm{T}$ cell-myocyte contact. Repeated allergen

\section{Figure 8}

Inhibition of CD4+ $\mathrm{T}$ cell apoptosis by direct T cellASM cell contact indicates bidirectional crosstalk. Purified OVA-stimulated CD4+ T cells were cocultured for 48 hours with ASM cells either separated in Transwells or in direct contact. Additionally, $\mathrm{CD} 4{ }^{+} \mathrm{T}$ cells were cocultured in contact with the ASM cells without prior stimulation in vitro. The cocultures were exposed to BrdU for 24 hours and the $\mathrm{CD} 4^{+} \mathrm{T}$ cells analyzed for BrdU incorporation and total cell DNA content. (A) BrdU versus DNA density plots shown with the corresponding DNA histograms. T cell BrdU incorporation plotted against DNA content defines the following regions: 1, live quiescent cells (absence of BrdU incorporation and in $\mathrm{G}_{0} / \mathrm{G}_{1}$ phase of the cell cycle); 2 , cells undergoing proliferation (incorporation of $\mathrm{BrdU}$ and in $S$ or $G_{2} / M$ phases of the cell cycle); 3, live postmitotic cells (incorporation of BrdU and again in $G_{0} / G_{1}$ phase of the cell cycle); 4, postactivation apoptotic cells (incorporation of BrdU and subdiploid DNA content); and 5, apoptotic quiescent cells (no BrdU incorporation and subdiploid DNA content). " $A$ " in the DNA histograms corresponds to the subdiploid or sub- $G_{0} / G_{1}$ region and represents both quiescent and postactivation apoptotic T cells. M, cells in mitosis. (B) The corresponding side (SSC-H) versus forward (FSC-H) scatter dot plots are multicolor gated in the BrdU/DNA density plot regions defined in A. (C) Quantitative analysis of the cytometric regions defined in $\mathbf{A}$ and $\mathbf{B}$. Data are from 4 independent experiments. ${ }^{*} P<0.05$. Apop, apoptotic cells; incorp, incorporation.

challenge induced a CD4 ${ }^{+} \mathrm{T}$ cell-dependent increase in ASM mass in vivo, which was associated with inhibition of apoptosis and increased proliferation of myocytes. In vitro, cell contact between activated $\mathrm{CD}^{+} \mathrm{T}$ cells and ASM cells led to reciprocal functional effects on cell cycle and survival, resulting in the induction of ASM cell proliferation and the reciprocal downregulation of $T$ cell apoptosis. Our data support a direct contribution of activated $\mathrm{CD} 4^{+} \mathrm{T}$ cells to the mechanism of ASM remodeling in asthma.

\section{Methods}

Animals, sensitization, airway challenge, and lung processing. Inbred brown Norway rats (Harlan UK Ltd.) were sensitized s.c. with 1 mg of OVA (SigmaAldrich) adsorbed in $100 \mathrm{mg}$ of aluminum hydroxide (EM Industries Inc.) and dissolved in PBS, and $0.5 \times 10^{9}$ heat-killed Bordetella pertussis bacilli i.p. (supplied by T. Issekutz, Dalhousie University, Halifax, Nova Scotia, Canada). For airway challenge, 5\% aerosolized OVA or BSA was delivered through orotracheal intubation using a rodent pulmonary mechanics system (Quadra-T; SCIREQ Inc.). For lung processing, 2 mM EDTA/PBS was perfused through the right ventricle; $\mathrm{BAL}$ was collected through tracheostomy; the lungs were fixed at $25 \mathrm{cmH}_{2} \mathrm{O}$ by tracheobronchial infusion of $4 \%$ paraformaldehyde/PBS or $10 \%$ formalin/PBS; and tissue sections were obtained in parahilar and midsagittal orientation. Alternatively, the lungs were digested in collagenase D (Roche Diagnostics Corp.) and lymphocytes separated by centrifugal gradient in Lympholyte-Rat (Cedarlane Laboratories Ltd.). The study protocol complied with the guidelines of the 


\section{Table 2}

CD4+ T cell proliferation and cell cycle following coculture with ASM cells

\begin{tabular}{|c|c|c|c|}
\hline & $\begin{array}{c}\text { OVA } \\
\text { Transwell }\end{array}$ & $\begin{array}{c}\text { OVA } \\
\text { direct contact }\end{array}$ & $\begin{array}{c}\text { No-OVA } \\
\text { direct contact }\end{array}$ \\
\hline $\begin{array}{l}\text { Region } 1 \\
\text { BrdU-, } / G_{0} / G_{1}\end{array}$ & $\begin{array}{l}38.6 \pm 4.9 \\
P=0.130^{A}\end{array}$ & $\begin{array}{l}31.2 \pm 5.0 \\
P<0.001^{B}\end{array}$ & $\begin{array}{l}91.7 \pm 4.0 \\
P<0.001 \mathrm{C}\end{array}$ \\
\hline $\begin{array}{l}\text { Region } 2 \\
\mathrm{BrdU}^{+}, \mathrm{S} / \mathrm{G}_{2} / \mathrm{M}\end{array}$ & $\begin{array}{c}6.6 \pm 2.6 \\
P=0.006^{A}\end{array}$ & $\begin{array}{l}19.8 \pm 5.3 \\
P<0.001^{B}\end{array}$ & $\begin{array}{l}1.4 \pm 1.4 \\
P=0.260^{C}\end{array}$ \\
\hline $\begin{array}{l}\text { Region } 3 \\
\mathrm{BrdU}^{+}, \mathrm{G}_{0} / \mathrm{G}_{1}\end{array}$ & $\begin{array}{l}20.2 \pm 4.7 \\
P<0.001^{A}\end{array}$ & $\begin{array}{l}42.2 \pm 5.5 \\
P<0.001^{B}\end{array}$ & $\begin{array}{c}3.3 \pm 2.3 \\
P=0.004 \mathrm{C}\end{array}$ \\
\hline $\begin{array}{l}\text { Region } 4 \\
\text { BrdU+, subdiploid }\end{array}$ & $\begin{array}{l}25.0 \pm 5.6 \\
P<0.001^{A}\end{array}$ & $\begin{array}{c}6.1 \pm 0.7 \\
P=0.117^{B}\end{array}$ & $\begin{array}{c}2.2 \pm 2.3 \\
P<0.001^{C}\end{array}$ \\
\hline $\begin{array}{l}\text { Region } 5 \\
\text { BrdU-, subdiploid }\end{array}$ & $\begin{array}{l}10.4 \pm 7.5 \\
P=0.010^{A}\end{array}$ & $\begin{array}{c}1.4 \pm 0.6 \\
P=0.905^{B}\end{array}$ & $\begin{array}{c}1.1 \pm 0.3 \\
P=0.014^{C}\end{array}$ \\
\hline
\end{tabular}

CD4 ${ }^{+} T$ cells from OVA-sensitized rats were stimulated with OVA in vitro and cocultured with ASM cells for 48 hours, either separated by a Transwell membrane or in direct contact. Alternatively, the CD4+ $\mathrm{T}$ cells were added to the ASM cells without prior OVA stimulation, and contact was allowed. Subsequently, BrdU incorporation and cell cycle were analyzed in the $\mathrm{CD} 4^{+} \mathrm{T}$ cells. The region numbers correspond to the cytometric regions defined in Figure 8. Data are mean cell percentages

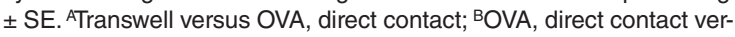
sus no-OVA, direct contact; ${ }^{\circ}$ Transwell versus no-OVA, direct contact.

Canadian Council on Animal Care and was approved by the Animal Care Committee of McGill University.

Antibodies. Monoclonal antibody to retroviral Env protein (86A25) (33) was provided by L.H. Evans (National Institute of Allergy and Infectious Diseases, Hamilton, Montana, USA). We purchased mAb to GFP (JL-8), FITC-conjugated rat anti-mouse CD8 (Ly-2), and $\mathrm{IgG}_{1}$ isotype control from $\mathrm{BD}$ Biosciences; $\mathrm{mAb}$ anti-rat myeloid differentiation antigen $\mathrm{CD} 172 \mathrm{a}$ (ED9) and FITC-labeled goat anti-mouse IgG, rat-adsorbed, from Serotec; $\mathrm{mAb}$ anti-rat $\mathrm{B}$ cell (OX33), $\mathrm{mAb}$ anti-rat CD8 (OX8), and $\mathrm{mAb}$ anti-rat CD4 (W3-25) from Cedarlane Laboratories Ltd.; magnetic microbeads conjugated to $\mathrm{mAb}$ anti-mouse $\operatorname{IgG}_{1}$ from Miltenyi Biotec; $\mathrm{mAb}$ to $\alpha$-SMA (1A4) and rabbit polyclonal antibody to pan-actin from Sigma-Aldrich; Alexa 488-labeled goat anti-mouse IgG and goat anti-rabbit immunoglobulins from Invitrogen Corp.; $\mathrm{mAb}$ to PCNA (Ab-1) from Calbiochem; and biotinylated horse anti-mouse IgG, rat-adsorbed, from Vector Laboratories.

Generation of a stable retrovirus packaging cell line. To generate recombinant retrovirus, we used the Phoenix-Eco packaging cell line (purchased from American Type Culture Collection). Cells were maintained in DMEM containing $10 \%$ heat-inactivated FBS, $2 \mathrm{mM}$ glutamine, $100 \mathrm{U} / \mathrm{ml}$ penicillin, and $100 \mu \mathrm{g} / \mathrm{ml}$ streptomycin (Invitrogen Corp.). Cells were transfected using Lipofectamine-2000 Plus (Invitrogen Corp.), with pIRESPUR plasmid $(0.5 \mu \mathrm{g})$ encoding puromycin resistance (BD Biosciences - Clontech) and PAP2 retrovector encoding EGFP ( $5 \mu \mathrm{g}$ linearized with Fsp1) (provided by J. Galipeau, McGill University) (34). We subsequently selected successfully transfected cells by culturing in media containing $2 \mu \mathrm{g} / \mathrm{ml}$ puromycin (Sigma-Aldrich). We then sorted the puromycin-resistant Phoenix-Eco population by FACS to select $\mathrm{EGFP}^{+}$cells expressing high levels of the retroviral $\mathrm{gag} / \mathrm{pol}$ and $e n v$ genes. We used for this purpose Ly- $2 \mathrm{mAb}$ to mouse CD8, which is coexpressed with $\mathrm{gag} / \mathrm{pol}$, and 86A25 mAb against Env protein. Retroviruses were titrated on NIH3T3 fibroblasts (ATCC).

$\mathrm{CD}^{+} \mathrm{T}$ cell stimulation and transduction. Cervical lymph node cell populations from OVA-sensitized rats were cultured at $5 \times 10^{6} \mathrm{cells} / \mathrm{ml}$ in complete DMEM supplemented with $50 \mu \mathrm{M}$ 2-Mercaptoethanol (Fisher Scientific International Inc.), 1\% nonessential amino acids (Invitrogen Corp.),
$200 \mu \mathrm{g} / \mathrm{ml} \mathrm{OVA}$, and $10 \mathrm{U} / \mathrm{ml}$ of rat IL-2 (BD Biosciences). Following 48 hours of stimulation, the cells were transduced by spin infection twice at $455 \mathrm{~g}$ for 45 minutes at $37^{\circ} \mathrm{C}$, with $6 \mu \mathrm{g} / \mathrm{ml}$ hexadimethrin bromide (Polybrene; Sigma-Aldrich), $10 \mathrm{U} / \mathrm{ml}$ rat IL-2 and approximately $10^{6}$ virions $/ \mathrm{ml}$, providing a multiplicity of infection of 2 . The $\mathrm{EGFP}^{+}$cells were sorted by FACS on day 6 and transferred to recipients. For $\mathrm{CD} 4^{+} \mathrm{T}$ cell negative selection, lymph node populations were incubated with ED9, OX-33, and OX-8 mAbs, labeled with magnetic microbeads and passed through a depletion column (Miltenyi Biotec).

Measurement of ASM mass. Lung sections were coimmunostained with anti- $\alpha$-SMA mAb (1A1), detected with Vector Red (Vector Laboratories), and polyclonal antibody to pan-actin, detected with Alexa 488. The airways were mapped with a confocal microscope (Axiovert 410; Zeiss) using a 20x objective lens and ASM extracted by channel subtraction. Vascular smooth muscle was then identified and eliminated with the aid of matched transmission images. We calculated ASM mass as ASM surface referenced to $\mathrm{P}_{\mathrm{BM}}{ }^{2}$ for airway size correction using Image-Pro Plus software version 4.0.0.13 (MediaCybernetics). $\mathrm{P}_{\mathrm{BM}}$ is a constant dimension in an airway section, independent of whether the airway is constricted or relaxed (35).

In situ colocalization of proliferation and apoptosis with ASM cells. PCNA detection was preceded by high-temperature epitope unmasking in antigen retrieval solution (Vector Laboratories) and permeabilization in $0.2 \%$ Triton X-100 (Sigma-Aldrich). Sections were then blocked with $20 \%$ horse serum (Vector Laboratories) in universal blocking solution (DakoCytomation), and Ab-1 $\mathrm{mAb}$ to PCNA was detected with biotinylated horse anti-mouse IgG, avidin/ biotin-alkaline phosphatase complex, and BCIP/NBT chromogen substrate (Vector Laboratories). Apoptosis was detected by TUNEL with an ApopTag peroxidase kit (Chemicon International) and enhanced DAB-Nickel (Vector Laboratories). Coimmunostaining with $1 \mathrm{~A} 4 \mathrm{mAb}$ was developed with Vector Red and followed by methyl green (Sigma-Aldrich) counterstain. In crosssectioned airways, $\mathrm{PCNA}^{+}$or TUNEL ${ }^{+}$cells were referenced to $\mathrm{P}_{\mathrm{BM}^{2}}$.

Primary ASM $/ \mathrm{CD}^{+}$T cell cocultures and flow cytometric analysis of DNA synthesis and cell cycle. ASM cell cultures were prepared from OVA-sensitized rats as described previously (36) (see Supplemental Methods). The ASM cells were subcultured onto 6 -well cell culture plates at a seeding density of $8 \times 10^{4}$ cells/well. When the cultures reached approximately $85 \%$ confluence by the third day of passage 1 subculture, the wells were washed 3 times with PBS, and the cells were placed in serum-free medium containing $0.2 \%$ BSA for 72 hours. At this point, the ASM cells were either stimulated with $10 \%$ FBS or incubated in DMEM:F12 containing 0.5\% FBS in the absence or presence of $\mathrm{CD}^{+} \mathrm{T}$ cells. $\mathrm{CD} 4^{+} \mathrm{T}$ cells were purified by immunomagnetic negative selection from cervical lymph node cell populations that were harvested from the same rats and stimulated with OVA in vitro, as described above. Four million $\mathrm{CD}^{+}{ }^{+} \mathrm{T}$ cells or a series of $\mathrm{T}$ cell numbers decreasing by 0.1 or 0.5 for dose-response titration, were added to each well of the serumdeprived ASM cell cultures, in DMEM:F12 (Invitrogen Corp.) media supplemented with $0.5 \% \mathrm{FBS}$. The activated $\mathrm{CD} 4^{+} \mathrm{T}$ cells were cultured either directly on the ASM cells or in the upper chamber of a Transwell Permeable Support (Corning Life Sciences). Alternatively, $\mathrm{CD}^{+}{ }^{+} \mathrm{T}$ cells purified from freshly harvested lymph nodes were added to the ASM cell cultures without in vitro stimulation. To monitor ASM cell proliferation, we added BrdU (BD Biosciences) to the culture media at a $50-\mu \mathrm{M}$ concentration for the last 24 hours of a 48-hour coculture period, at the end of which we collected the cells for analysis by trypsin treatment. The digestion with trypsin dissociated the adherent fraction of the $\mathrm{CD} 4^{+} \mathrm{T}$ cells from the ASM cells and produced mixed cell suspensions without doublets, as assessed by microscopy and flow cytometry. The cell suspensions were labeled with APC-anti$\mathrm{CD} 4 \mathrm{mAb}$ and processed for the flow cytometric detection of incorporated BrdU and cell DNA content using an FITC-BrdU Flow Kit (BD Biosciences) according to the manufacturer's instructions. 
Statistical analysis. Data are expressed as mean \pm SE unless otherwise indicated. Multiple comparisons were analyzed with 1-way ANOVA followed by post-ANOVA Fisher's least significant difference test. The $95 \%$ confidence interval of the mean difference was calculated to estimate the size of effects in post-ANOVA pairwise comparisons. Association patterns were explored by best-fit regression modeling. Strength of association is expressed by $r$ or $r^{2}$. A $P$ value less than 0.05 was considered significant. Data analysis was performed with the SPSS statistical software package version 12.0 (SPSS Inc.) and the regression module of SigmaPlot 2000 version 6.00 (SYSTAT Software Inc.).

\section{Acknowledgments}

D. Ramos-Barbón is a recipient of a Canadian Institutes of Health Research/Canadian Lung Association (CIHR/Canadian Lung Association) fellowship. E.D. Fixman is a recipient of a salary award from the Fonds de la Recherche en Santé du Québec. This research was supported by operating funds from the CIHR (to Q.A. Hamid, J.G. Martin, and E.D. Fixman; MOP-36516 and MOP-64362) and a CIHR/AstraZeneca-Canada Rx\&D Fellowship Award (to D. Ramos-Barbón). We wish to thank J. Galipeau and
D. Jaalouk, of the Division of Hematology-Oncology, Lady Davis Institute for Medical Research, McGill University, for their assistance in the generation of stable retrovirus packaging cell lines and transduction techniques and for generously providing the pAP2 retrovector; and L.H. Evans for providing $\mathrm{mAb}$ against retroviral Env protein. D. Ramos-Barbón received the 2004 CIHR Young Investigators Forum in Circulatory and Respiratory Health Postdoctoral Award (Eldon R. Smith Award) and the 2004 European Respiratory Society Clinical Allergy and Immunology Award 1st prize (supported by GlaxoSmithKline) for this work.

Received for publication August 4, 2003, and accepted in revised form March 16, 2005.

Address correspondence to: J.G. Martin or E.D. Fixman, MeakinsChristie Laboratories, McGill University, 3626 Saint Urbain Street, Montreal, Quebec H2X 2P2, Canada. Phone: (514) 398-3864, ext. 00137; Fax: (514) 398-7483; E-mail: james.martin@mcgill.ca (J.G. Martin). Phone: (514) 398-3864, ext. 00140; Fax: (514) 398-7483; elizabeth.fixman@mcgill.ca (E.D. Fixman).
1. Bousquet, J., Jeffery, P.K., Busse, W.W., Johnson, M., and Vignola, A.M. 2000. Asthma. From bronchoconstriction to airways inflammation and remodeling. Am. J. Respir. Crit. Care Med. 161:1720-1745.

2. Elias, J.A., et al. 2003. New insights into the pathogenesis of asthma. J. Clin. Invest. 111:291-297. doi:10.1172/JCI200317748.

3. James, A.L., Pare, P.D., and Hogg, J.C. 1989. The mechanics of airway narrowing in asthma. Am. Rev. Respir. Dis. 139:242-246.

4. Lambert, R.K., Wiggs, B.R., Kuwano, K., Hogg, J.C., and Pare, P.D. 1993. Functional significance of increased airway smooth muscle in asthma and COPD. J. Appl. Physiol. 74:2771-2781.

5. Robinson, D.S., et al. 1992. Predominant TH2like bronchoalveolar T-lymphocyte population in atopic asthma. N. Engl. J. Med. 326:298-304.

6. Gavett, S.H., et al. 1995. Interleukin 12 inhibits antigen-induced airway hyperresponsiveness, inflammation, and Th2 cytokine expression in mice. J. Exp. Med. 182:1527-1536.

7. Ying, S., et al. 1997. Expression of IL-4 and IL-5 mRNA and protein product by CD4+ and CD8+ T cells, eosinophils, and mast cells in bronchial biopsies obtained from atopic and nonatopic (intrinsic) asthmatics. J. Immunol. 158:3539-3544.

8. Lazaar, A.L., et al. 1994. T lymphocytes adhere to airway smooth muscle cells via integrins and CD44 and induce smooth muscle cell DNA synthesis. J. Exp. Med. 180:807-816.

9. Sapienza, S., Du, T., Eidelman, D.H., Wang, N.S., and Martin, J.G. 1991. Structural changes in the airways of sensitized brown Norway rats after antigen challenge. Am. Rev. Respir. Dis. 144:423-427.

10. Watanabe, A., et al. 1995. Transfer of allergic airway responses with antigen-primed CD4+ but not CD8+ T cells in brown Norway rats. J. Clin. Invest. 96:1303-1310.

11. Costa, G.L., et al. 2000. Targeting rare populations of murine antigen-specific $\mathrm{T}$ lymphocytes by retroviral transduction for potential application in gene therapy for autoimmune disease. J. Immunol. 164:3581-3590.

12. Ridgway, W., Fasso, M., and Fathman, C.G. 1998. Following antigen challenge, $\mathrm{T}$ cells up-regulate cell surface expression of CD4 in vitro and in vivo. J. Immunol. 161:714-720.

13. Wise, J.T., Baginski, T.J., and Mobley, J.L. 1999. An adoptive transfer model of allergic lung inflammation in mice is mediated by $\mathrm{CD} 4+\mathrm{CD} 62 \mathrm{~L}^{\text {low }} \mathrm{CD} 25+$
T cells. J. Immunol. 162:5592-5600.

14. Paterson, D.J., et al. 1987. Antigens of activated rat $\mathrm{T}$ lymphocytes including a molecule of $50,000 \mathrm{Mr}$ detected only on CD4 positive T blasts. Mol. Immunol. 24:1281-1290.

15. Weinberg, A.D., Wegmann, K.W., Funatake, C., and Whitham, R.H. 1999. Blocking OX-40/OX40 ligand interaction in vitro and in vivo leads to decreased $\mathrm{T}$ cell function and amelioration of experimental allergic encephalomyelitis. J. Immunol. 162:1818-1826.

16. Wiggs, B.R., Moreno, R., Hogg, J.C., Hilliam, C., and Pare, P.D. 1990. A model of the mechanics of airway narrowing. J. Appl. Physiol. 69:849-860.

17. Leigh, R., et al. 2002. Dysfunction and remodeling of the mouse airway persist after resolution of acute allergen-induced airway inflammation. Am. J. Respir. Cell Mol. Biol. 27:526-535.

18. Watanabe, A., et al. 1997. Adoptively transferred late allergic airway responses are associated with Th2-type cytokines in the rat. Am. J. Respir. Cell Mol. Biol. 16:69-74.

19. Panettieri, R.A., Jr., Murray, R.K., Eszterhas, A.J., Bilgen, G., and Martin, J.G. 1998. Repeated allergen inhalations induce DNA synthesis in airway smooth muscle and epithelial cells in vivo. Am. J. Physiol. 274:L417-L424.

20. Salmon, M., et al. 1999. Involvement of cysteinyl leukotrienes in airway smooth muscle cell DNA synthesis after repeated allergen exposure in sensitized Brown Norway rats. Br. J. Pharmacol. 127:1151-1158.

21. Salmon, M., Walsh, D.A., Koto, H., Barnes, P.J., and Chung, K.F. 1999. Repeated allergen exposure of sensitized Brown-Norway rats induces airway cell DNA synthesis and remodelling. Eur. Respir. J. 14:633-641.

22. Lazaar, A.L., et al. 1998. CD40-mediated signal transduction in human airway smooth muscle. J. Immunol. 161:3120-3127.

23. Lazaar, A.L., Krymskaya, V.P., and Das, S.K. 2001. VCAM-1 activates phosphatidylinositol 3-kinase and induces $\mathrm{p} 120 \mathrm{Cbl}$ phosphorylation in human airway smooth muscle cells. J. Immunol. 166:155-161.

24. de La Motte, C.A., Hascall, V.C., Calabro, A., YenLieberman, B., and Strong, S.A. 1999. Mononuclear leukocytes preferentially bind via CD44 to hyaluronan on human intestinal mucosal smooth muscle cells after virus infection or treatment with poly(I.C). J. Biol. Chem. 274:30747-30755.
25. Salmon, M., et al. 2000. Contribution of upregulated airway endothelin-1 expression to airway smooth muscle and epithelial cell DNA synthesis after repeated allergen exposure of sensitized Brown-Norway rats. Am. J. Respir. Cell Mol. Biol. 23:618-625.

26. Wang, C.G., Du, T., Xu, L.J., and Martin, J.G. 1993. Role of leukotriene D4 in allergen-induced increases in airway smooth muscle in the rat. Am. Rev. Respir. Dis. 148:413-417.

27. Lee, J.H., et al. 2001. Interleukin-13 induces dramatically different transcriptional programs in three human airway cell types. Am. J. Respir. Cell Mol. Biol. 25:474-485.

28. Zimmermann, N., et al. 2003. Dissection of experimental asthma with DNA microarray analysis identifies arginase in asthma pathogenesis. J. Clin. Invest. 111:1863-1874. doi:10.1172/JCI200317912.

29. Panettieri, R.A., Jr. 2002. Airway smooth muscle: an immunomodulatory cell [review]. J. Allergy Clin. Immunol. 110(6 Suppl.):S269-S274.

30. Hamann, K.J., et al. 2000. Fas cross-linking induces apoptosis in human airway smooth muscle cells. Am. J. Physiol. Lung Cell Mol. Physiol. 278:L618-L624.

31. Geng, Y.J., Henderson, L.E., Levesque, E.B., Muszynski, M., and Libby, P. 1997. Fas is expressed in human atherosclerotic intima and promotes apoptosis of cytokine-primed human vascular smooth muscle cells. Arterioscler. Thromb. Vasc. Biol. 17:2200-2208.

32. Hamann, K.J., et al. 1998. Expression of Fas (CD95) and FasL (CD95L) in human airway epithelium. Am. J. Respir. Cell Mol. Biol. 19:537-542.

33. Evans, L.H., Morrison, R.P., Malik, F.G., Portis, J., and Britt, W.J. 1990. A neutralizable epitope common to the envelope glycoproteins of ecotropic, polytropic, xenotropic, and amphotropic murine leukemia viruses. J. Virol. 64:6176-6183.

34. Galipeau, J., et al. 1999. Vesicular stomatitis virus G pseudotyped retrovector mediates effective in vivo suicide gene delivery in experimental brain cancer. Cancer Res. 59:2384-2394.

35. James, A.L., Hogg, J.C., Dunn, L.A., and Pare, P.D. 1988. The use of the internal perimeter to compare airway size and to calculate smooth muscle shortening. Am. Rev. Respir. Dis. 138:136-139.

36. Zacour, M.E., and Martin, J.G. 1996. Enhanced growth response of airway smooth muscle in inbred rats with airway hyperresponsiveness. Am. J. Respir. Cell Mol. Biol. 15:590-599. 